\title{
Control of bleaching in mushroom coral populations (Scleractinia: Fungiidae) in the Java Sea: stress tolerance and interference by life history strategy
}

\author{
Bert W. Hoeksema* \\ National Museum of Natural History, PO Box 9517, 2300 RA Leiden, The Netherlands
}

\begin{abstract}
B Bleaching was studied in populations of phylogenetically closely related species $(n=21)$ of mushroom corals (Scleractinia: Fungiidae) around Pari Island (Java Sea) during a period of excessive seawater warming in 1983. The interspecific variation in the proportions of affected individuals was significant. Spatial variation in the degree of bleaching among fungiid assemblages depended much on relative species abundances. Mushroom corals in relatively stagnant water of lagoons and on the inner reef flat showed little bleaching. Many of the outer reef mushroom corals at $\leq 9 \mathrm{~m}$ depth were affected, but only a few at greater depths $(\geq 15 \mathrm{~m}$ ). In most affected fungiids, the bleached part was pale (associated with pigment loss) instead of white (assumedly caused by zooxanthellae expulsion). The difference between the proportions of paled and whitened corals was not clearly depth-related, but most probably species-related. Most bleached fungiids were affected over their whole upper surface, whereas others showed a mosaic pattern. Entire bleaching was most common at depths $<6 \mathrm{~m}$ and partial bleaching at $9 \mathrm{~m}$. One species with a predominantly shallow distribution (mainly $\leq 9 \mathrm{~m}$ ) showed a significant majority of entirely bleached individuals. The smallest mushroom corals $\left(\varnothing_{\max } \leq 5 \mathrm{~cm}\right)$ on the outer reef, usually in sheltered positions, and the largest ones $\left(\varnothing_{\max }>20 \mathrm{~cm}\right)$, usually occurring deep, were the least affected. The latter may have escaped bleaching by recurrent downward migration.
\end{abstract}

\section{INTRODUCTION}

During the last decade, bleaching and subsequent mortality in zooxanthellate corals has occurred as a circumtropical series of events (Brown 1987, Glynn 1990, Williams \& Bunkley-Williams 1990). Bleaching may result from expulsion of symbiotic algae known as zooxanthellae, usually visible as complete discoloration (whitening) of the corals, whereas it has also been attributed to a degeneration of zooxanthellar chloroplasts with a subsequent pigmentation decrease, which may be observed as paling (Jaap 1985, Gladfelter 1988, Hoegh-Guldberg \& Smith 1989, Kleppel et al. 1989, Jokiel \& Coles 1990, Szmant \& Gassman 1990). On a local scale, besides interspecific variation in bleaching

\footnotetext{
- Present address: Department of Invertebrate Zoology, National Museum of Natural History, Smithsonian Institution, Washington, D.C. 20560 , USA.
}

patterns, there are also intraspecific differences in coral bleaching, which appear partially related to spatial, bathymetric and size distributions (Faure et al. 1984, Fisk \& Done 1985, Harriott 1985, Lang et al. 1988). However, detailed information on bathymetric patterns in bleaching has not been available, and it is not precisely known how these patterns interact with the size distributions within coral populations.

It has been proposed that bleaching is caused by stress, such as excessive light and UV irradiance, prolonged darkness, anomalously high or low temperatures, abnormal salinities, increased suspended sediment load or a synergistic effect of these (Bak 1978 , Dustan 1982, Rogers 1983, Oliver 1985, Peters \& Pilson 1985, Acevedo \& Goenaga 1986, Steen \& Muscatine 1987, Jokiel 1988, Jokiel \& Coles 1990), but sometimes no presumable cause can be found (Ghiold \& Smith 1990, Goreau \& Macfarlane 1990). In studies on the occurrence of bleaching it is important to consider how 
such stresses relate to the tolerances within local populations (Brown \& Howard 1985). Accurate records of species distribution patterns and demographic constitutions of the populations are basic requirements for such assessments.

In the present study, mushroom corals (Fungiidae) have been selected for a comparison of bleaching among phylogenetically closely related species (Hoeksema 1989). Their bleaching patterns were studied off Jakarta, in the western part of the shallow Java Sea, Indonesia. Bleaching also occurred in the central Java Sea (Suharsono \& Kiswara 1984), but not more eastward, in the southern Makassar Strait (W. Moka pers. comm.). Although the reefs off Jakarta are affected by increasing siltation and urban pollution (Robinson et al. 1981, Moll \& Suharsono 1986 , Soemodihardjo 1986, Purwanto 1987. Sukarno 1987), the 1983 bleaching event was thought to be mainly associated with anomalously high seawater temperatures (Suharsono \& Kiswara 1984, Harger 1986, Brown 1987, Brown \& Suharsono 1990).

Compared to other reef-dwelling scleractinians, mushroom corals have an important practical advantage in quantitative ecological surveys: as distinct individuals they can easily be counted in the field (Hoeksema 1990). This enabled the study to concentrate on interspecific variation in the kinds and patterns of bleaching, the proportions of affected individuals (especially with regard to their sizes), and how these are related to their spatial and bathymetric distributions.

\section{STUDY SITE AND METHODS}

Fieldwork was performed from April to June 1983, around the Pari Island group, which is a reef in the southernmost part of the Thousand Islands ('Kepulauan Seribu'), an island chain extending NNW off Jakarta (Umbgrove 1929, Ongkosongo \& Sukarno 1986). The reef is located $17 \mathrm{~km}$ off Java's mainland $\left(5^{\circ} 52^{\prime} \mathrm{S}, 107^{\circ}\right.$ $\left.37^{\prime} \mathrm{E}\right)$. Pari Island and some smaller islets are arranged around a series of lagoons, which are connected with the surrounding sea by shallow tidal channels (Fig. 1). The monsoon-driven surf (Umbgrove 1929) has caused the emergence of prominent shingle ramparts at the $\mathrm{E}$ and SE sides of the reef flat and smaller ones at the $W$ and NW sides (Fig. 2). The small ramparts may not always be discernable, since they were not noticed in 1979 during the study by Brown et al. (1983).

Coral bleaching at Pari Island was first noticed in April 1983 during a period of excessive seawater warming that lasted until the end of July (Brown \& Suharsono 1990). To assess the occurrence of bleaching among mushroom corals, 7 transect sites were selected around the reef (Fig. 1): W (2 to 4 June), NW (26 to 29 May), $N$ (23 to 24 May), E (16 to 18 May), SE (5 to 6 June), SW1 ( 7 to 10 June) and SW2 (19 to 21 May). Sites SW1 and SW2 are located close to a tidal channel where strong currents occur (own obs.).

In the transects, $2 \times 10 \mathrm{~m}^{2}$ sample quadrats were surveyed on the inner reef flat ( $\leq 1 \mathrm{~m}$ depth) and on the outer reef flat (1,2 and $3 \mathrm{~m}$ ) using snorkel equipment, and on the reef slope and base $(6,9,15$ and $21 \mathrm{~m})$ with the use of SCUBA (Fig. 2). A $10 \mathrm{~m}$ long fiberglass measuring tape was placed along the respective isobaths and a $1 \mathrm{~m}$ long PVC tube was guided alongside to demarcate the width of the quadrats. The depths of the quadrats were chosen to obtain an approximately even distribution of the quadrats over the reef profile, down to the maximum depth of mushroom coral occurrence (Fig. 2). The number of selected depths and the size of the quadrats were both limited by the available underwater time. Quadrats that did not contain fungiids usually also did not show any fungiids around them. Each mushroom coral was identified and its length $\left(\varnothing_{\max } \pm 0.5 \mathrm{~cm}\right)$ was measured along the aboral surface. Furthermore, numbers of paled and whitened, and partially and entirely affected corals were noted. The number of recently killed corals (those not yet covered by filamentous algae) was low and since their cause of death was uncertain, they were not counted in the assessment. In addition, 2 lagoon

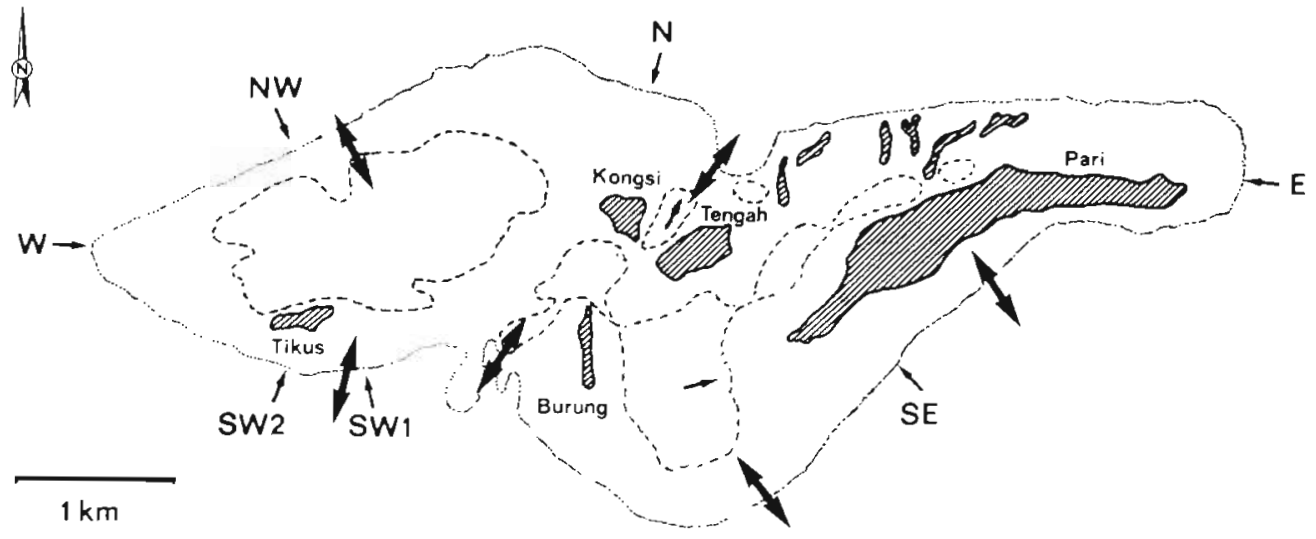

Fig. 1. Pari Island group with indication of study sites (small. arrows), islets (hatched), lagoons (dotted) and tidal channels (large double-sided arrows) 

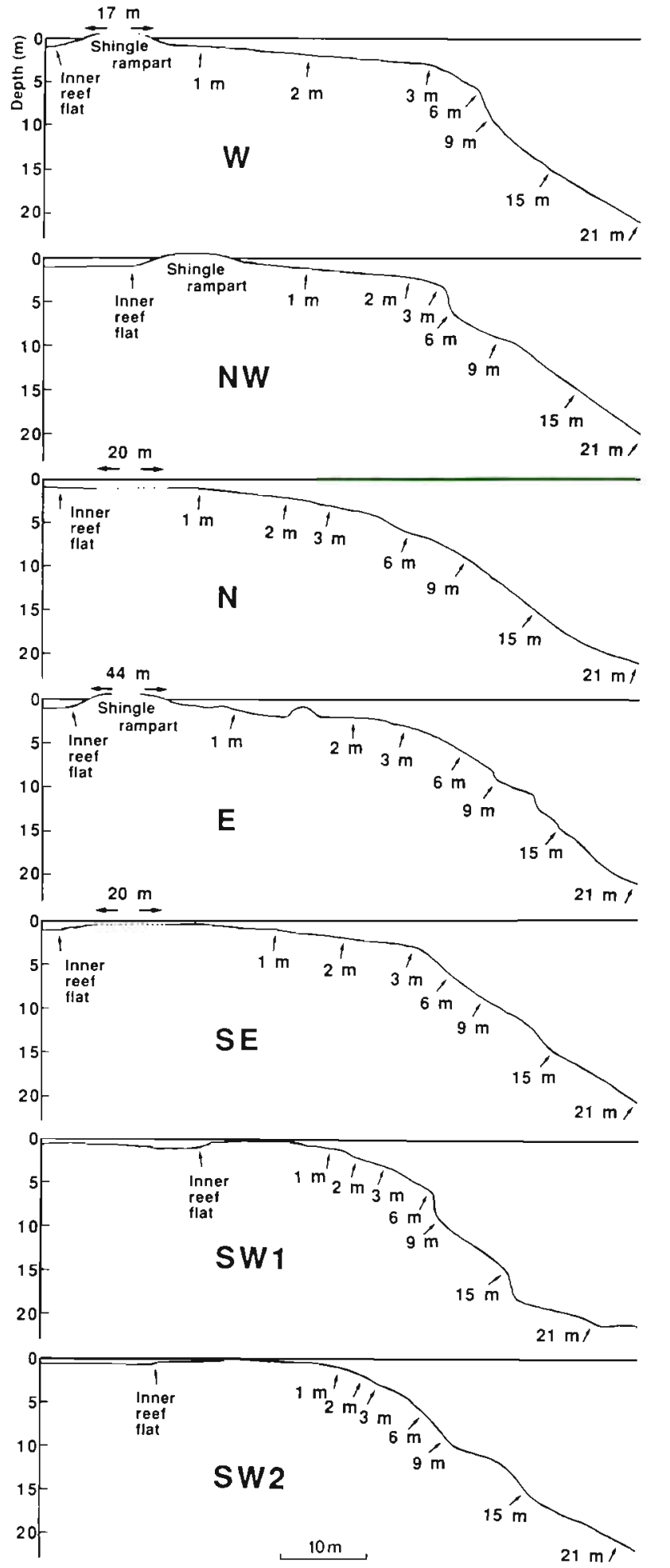

Fig. 2. Reef profiles of the 7 transect sites

sites were investigated (down to $4 \mathrm{~m}$ depth): one NW off Tengah I. (5 June), and one SW off Pari I. (27 April). Since mushroom corals showed a patchy distribution in the lagoons, fungiid assemblages were only checked for the occurrence of bleaching.

In the outer reef zone, per transect the largest populations ( $\mathrm{n}>50$ corals) were studied to investigate whether bleaching was size-dependent. Since mushroom corals are known to migrate (Hoeksema 1988), coral sizes may differ among the investigated depths. Therefore, variation of mean length among the quadrats was tested with a 1-way ANOVA. Regression analyses were used to find out whether positive correlations between size and depth could be detected. All statistics were calculated with computer programs by Glantz (1988).

Subgenera of Fungia (see Hoeksema 1989) are hereafter abbreviated as: C., Cycloseris; V., Verrillofungia; $D$., Danafungia; $F$., Fungia; W., Wellsofungia; L., Lobactis; P., Pleuractis.

\section{RESULTS}

\section{Mushroom coral abundances}

Mushroom corals were irregularly distributed over the study sites (Table 1). This uneven distribution cannot be directly attributed to wind-energy exposure. Among the shallowest quadrats ( $\leq 2 \mathrm{~m}$ deep), the least exposed transects (SW1 and SW2) showed generally higher mushroom coral densities than the other sites (Table 1). Because of the mobility during the free-living stage in their life history (Hoeksema 1988), the distribution of fungiids is probably influenced by bottom relief (Fig. 2). The highest densities of fungiids were usually encountered at 3 to $9 \mathrm{~m}$ depth, whereas the inner reef flat also showed some high concentrations of mushroom corals (Table 1 ).

A total of 21 species was recorded, 8 of which were observed at each of the 7 sites; some were found in high densities and in wide bathymetric ranges (Fig. 3). The highest species richness was encountered at Site W, whereas Site E showed the lowest (Table 2). The highest numbers of species within the transects usually occurred at either 6,9 , or $15 \mathrm{~m}$ depth, and the lowest on the inner reef flat, or on the outer reef at 1 or $21 \mathrm{~m}$ (Table 2). Inside the lagoons, clusters of mushroom corals were usually found down to $2 \mathrm{~m}$ deep.

\section{Bleaching in mushroom coral populations}

During the 1983 bleaching event in the Java Sea, the upper surfaces of many fungiid corals occurred in various stages of discoloration. The usual brown was partly or completely replaced by a pale brown or yellow (like lemon or ocher), or by a translucent white. The undersides, which were usually in contact with the bottom, 

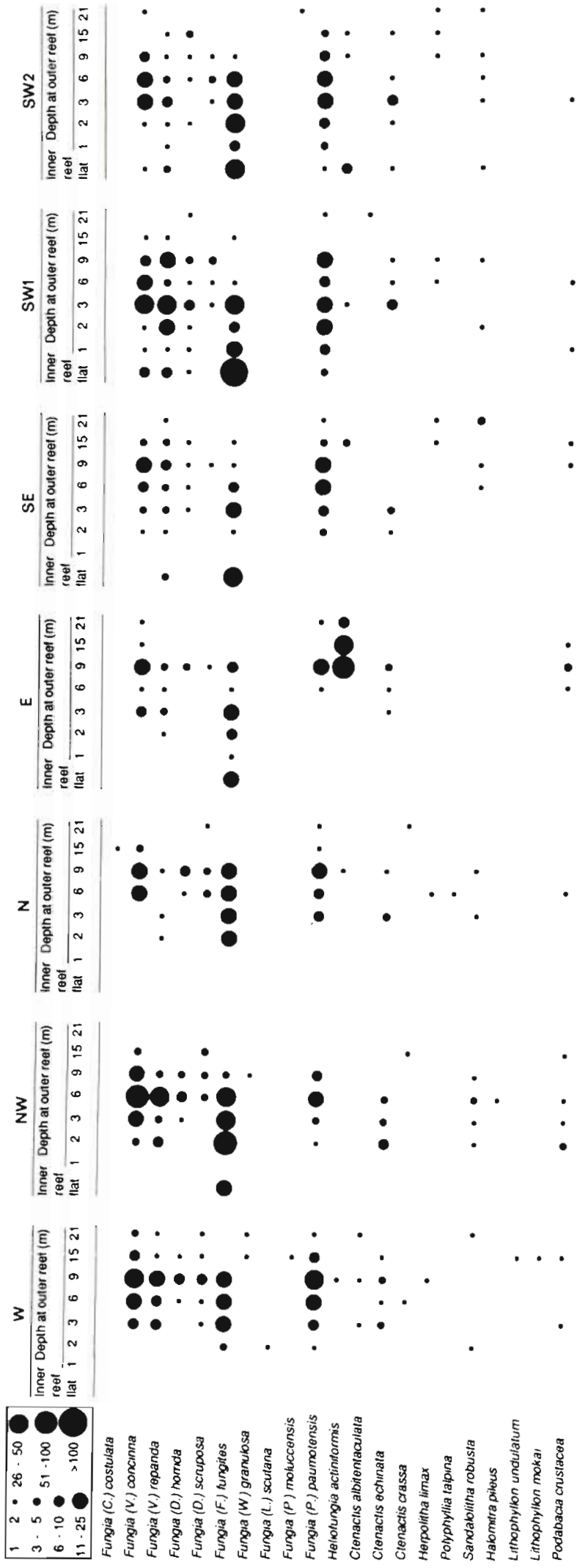

Fig. 3. Abundances of mushroom coral species in $2 \times 10 \mathrm{~m}^{2}$ quadrats at several depths in each of the transects were light-colored in bleached individuals and in unbleached ones as well. Some corals appeared to pale or whiten over their whole upper surface at once, whereas others started either in a patchy pattern, around the mouth or at the polyp periphery (Fig. 4). At the lagoon sites, no mushroom coral bleaching was observed. In the transects, $44 \%$ of all studied specimens ( $\mathrm{n}=2064)$ were bleached. Quadrats with more than $50 \%$ affected corals were found on the outer reef from 1 to $9 \mathrm{~m}$ deep (Table 3 ). On the inner reef flat, $14 \%$ of the fungiids were affected, whereas overall bleaching on the outer reef was $48 \%$ (Table 4). The proportions of affected mushroom corals on the inner reef flat varied significantly $\left(\chi^{2}=9.22, p<0.05\right)$. They were most concentrated at Sites SW1 and SW2 (Table 3; Fig. 5), each at a side of a tidal channel (Fig. 1), with $19 \%$ of the observed fungiids bleached, whereas in the other transects (NW, E, and SE) only $2 \%$ appeared affected.

Bleaching varied significantly among the investigated depths on the outer reef, most specifically with regard to paling and entire bleaching (Table 4). Mushroom corals at 2 to $6 \mathrm{~m}$ depth showed the highest percentages, whereas at 15 to $21 \mathrm{~m}$ only few individuals were affected. On the entire outer reef, significantly more paled than whitened fungiids were counted, but at no particular depth could such a significant difference be detected (Table 4). At shallow depths, completely bleached mushroom corals were usually more abundant than partially affected ones (significant at 2 and $3 \mathrm{~m}$ ), whereas at $6 \mathrm{~m}$ they were equally abundant. At $9 \mathrm{~m}$ depth, partially bleached fungiids were significantly more abundant than completely affected ones (Table 4).

The degree of bleaching among outer reef mushroom coral populations varied significantly with regard to all distinguished categories (Table 5). For example, the percentage of affected Fungia (V.) repanda was much higher than that of all other species $\left(\chi^{2}=15.59\right.$, $p<0.001$ ), whereas populations of Heliofungia actiniformis and Ctenactis echinata each displayed significantly lower percentages than the rest of the species $\left(\chi^{2}=58.67, p<0.001\right.$ and $\chi^{2}=5.53, p<0.05$, respectively). Significantly more mushroom corals, individuals of $F$. $(V$.) repanda in particular, were paled than whitened (Table 5). Entirely bleached fungiids, especially $F$. (F.) fungites, were significantly more abundant than partially affected ones.

On the outer reef, the transects showed a significant variation $\left(\chi^{2}=38.56, p<0.001\right)$ in mushroom coral bleaching (Table 3 ). There was no significant relation between the time order of measurement and the percentage of bleached animals for the sites (Spearman rank order $r_{\mathrm{s}}=0.64, \mathrm{p}=0.11$ ); there was also no significant relation with the density per site $\left(r_{\mathrm{s}}=0.39\right.$, 
Table 1 Density of fungiids $\left(\mathrm{m}^{-2}\right)$ at various depths (measured in $2 \times 10 \mathrm{~m}^{2}$ quadrats) and their total number ( $\mathrm{n}$ ) per site around Pari Island

\begin{tabular}{|c|c|c|c|c|c|c|c|c|c|}
\hline \multirow[t]{2}{*}{ Site } & \multirow{2}{*}{$\begin{array}{c}\text { Inner } \\
\text { reef } \\
\text { flat }\end{array}$} & \multicolumn{7}{|c|}{ Depth at outer reef $(\mathrm{m})$} & \multirow{2}{*}{$\begin{array}{c}\text { Total } \\
\text { (n) }\end{array}$} \\
\hline & & 1 & 2 & 3 & 6 & 9 & 15 & 21 & \\
\hline W & 0.00 & 0.00 & 0.30 & 2.75 & 3.45 & 6.70 & 1.25 & 0.70 & 303 \\
\hline NW & 1.10 & 0.00 & 385 & 3.75 & 9.25 & 2.65 & 0.55 & 0.00 & 423 \\
\hline $\mathrm{N}$ & 0.00 & 0.00 & 0.85 & 1.35 & 2.30 & 4.30 & 0.30 & 0.15 & 185 \\
\hline E & 1.15 & 0.10 & 0.35 & 1.55 & 0.45 & 5.60 & 1.85 & 0.45 & 230 \\
\hline SE & 1.80 & 0.00 & 0.50 & 2.05 & 1.55 & 2.25 & 1.00 & 0.30 & 189 \\
\hline SW1 & 6.75 & 1.35 & 1.70 & 8.10 & 1.60 & 2.20 & 0.30 & 0.15 & 443 \\
\hline SW2 & 2.55 & 0.65 & 2.35 & 3.95 & 2.85 & 1.50 & 0.50 & 0.20 & 291 \\
\hline
\end{tabular}

Table 2. Number of mushroom coral species $\left(\mathrm{m}^{-2}\right)$ at various depths (measured in $2 \times 10 \mathrm{~m}^{2}$ quadrats) and their total number per site $(n)$ around Pari Island

\begin{tabular}{|c|c|c|c|c|c|c|c|c|c|}
\hline \multirow[t]{2}{*}{ Site } & \multirow{2}{*}{$\begin{array}{c}\text { Inner } \\
\text { reef } \\
\text { flat }\end{array}$} & \multicolumn{7}{|c|}{ Depth at outer reef $(\mathrm{m})$} & \multirow{2}{*}{$\begin{array}{c}\text { Total } \\
\text { (n) }\end{array}$} \\
\hline & & 1 & 2 & 3 & 6 & 9 & 15 & 21 & \\
\hline W & 0.00 & 0.00 & 0.20 & 0.40 & 0.40 & 0.50 & 0.55 & 0.35 & 18 \\
\hline NW & 0.05 & 0.00 & 0.35 & 0.40 & 0.50 & 0.40 & 0.20 & 0.00 & 12 \\
\hline $\mathrm{N}$ & 0.00 & 0.00 & 0.10 & 0.25 & 0.25 & 0.40 & 0.45 & 0.15 & 14 \\
\hline$E$ & 0.05 & 0.05 & 0.10 & 0.20 & 0.30 & 0.45 & 0.15 & 0.15 & 9 \\
\hline SE & 0.10 & 0.00 & 0.25 & 0.30 & 0.30 & 0.40 & 0.40 & 0.20 & 11 \\
\hline SW1 & 0.25 & 0.30 & 0.30 & 0.40 & 0.45 & 0.40 & 0.15 & 0.15 & 12 \\
\hline SW2 & 0.35 & 0.15 & 0.30 & 0.40 & 0.40 & 0.45 & 0.35 & 0.20 & 12 \\
\hline
\end{tabular}

Table 3. Percentages of mushroom corals affected by bleaching in $2 \times 10 \mathrm{~m}^{2}$ quadrats at various depths per site around Pari Island $(>50 \%$ in boldface)

\begin{tabular}{|c|c|c|c|c|c|c|c|c|c|}
\hline \multirow[t]{2}{*}{ Site } & \multirow{2}{*}{$\begin{array}{c}\text { Inner } \\
\text { reet } \\
\text { flat }\end{array}$} & \multicolumn{7}{|c|}{ Depth at outer reef (m) } & \multirow{2}{*}{$\begin{array}{c}\text { Total } \\
\text { outer } \\
\text { reef }\end{array}$} \\
\hline & & 1 & 2 & 3 & 6 & 9 & 15 & 21 & \\
\hline W & & & 50 & 58 & 75 & 54 & 12 & 7 & 54 \\
\hline NW & 5 & & 52 & 65 & 65 & 53 & 0 & & 59 \\
\hline$N$ & & & 71 & 52 & 50 & 33 & 17 & 0 & 42 \\
\hline$E$ & 0 & 50 & 29 & 65 & 67 & 6 & 0 & 0 & 17 \\
\hline SE & 3 & & 70 & 63 & 61 & 58 & 0 & 17 & 55 \\
\hline SW1 & 13 & 30 & 47 & 68 & 25 & 45 & 0 & 0 & 53 \\
\hline SW2 & 35 & 54 & 74 & 44 & 44 & 20 & 0 & 0 & 45 \\
\hline
\end{tabular}

$\mathrm{p}=0.35)$, nor with the numbers of species $\left(r_{\mathrm{s}}=0.18\right.$, $p=0.66$ ). Therefore, the observed spatial variation was not time-, density-, or diversity-dependent. Fungiids on the outer reef of Site $E$ were significantly less affected than those at other sites $\left(\chi^{2}=32.19, \mathrm{p}<0.001\right)$, whereas those at Site NW were significantly more affected $\left(\chi^{2}=\right.$ 5.94, $\mathrm{p}<0.05)$. If the unaffected Heliofungia actiniformis would not be considered, there would be no significant variation in bleaching among the sites $\left(\chi^{2}=7.21\right.$, $p>0.05$ ), Site $E$ would not show a significantly lower percentage of bleached fungiids $\left(\chi^{2}=2.59, \mathrm{p}>0.05\right)$, and Site NW not a higher one $\left(\chi^{2}=2.78, \mathrm{p}>0.05\right)$.

On the inner reef flat, where mushroom coral bleach- ing was relatively rare (Table 3), no significant variation in bleaching among different size classes (Fig. 5) of mushroom corals could be detected $\left(\chi^{2}=1.30\right.$, $p>0.05)$. In the analysis of the outer reef corals, those belonging to Fungia (F.) fungites, the most dominant species, and the rest of the species, pooled for sufficient representation in all size classes, are considered separately. $F$. ( $F$.) fungites has a prevalent shallow distribution (Fig. 3), whereas the other species are represented more abundantly at greater depths.

Fungia (F.) fungites and all other funguid species showed significant variations in bleaching among the 5 distinguished size classes (Fig. 5; Table 6). This 

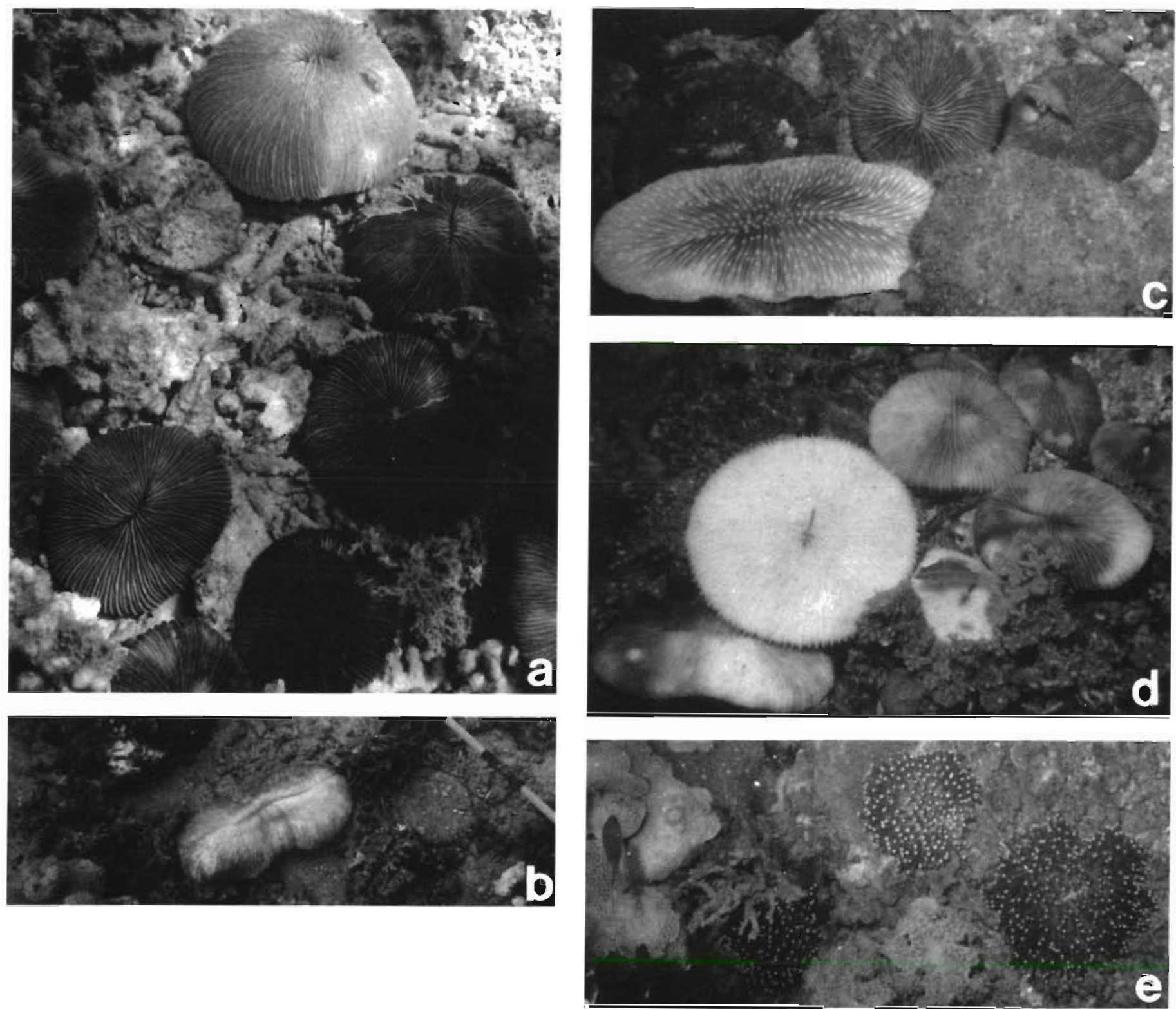

Fig. 4. Mushroom corals showing various degrees of bleaching: (a) Fungia (F.) fungites (Linnaeus), one coral completely pale, some showing white patches and the others brown (inner reef flat at Site SW2); (b) Ctenactis echinata (Pallas), whitened around the mouth ( $9 \mathrm{~m}$ at Site SW2): (c) C. albitentaculata Hoeksema paratype (RMNH 16103), whitened at periphery, and 3 individuals of $F$. (V.) concinna Verrill displaying white spotting (21 $\mathrm{m}$ at Site $W$ ); (d) $F$ (V.) repanda Dana, circular corals completely white or pale and $F$. (P.) paumotensıs Stutchbury, elongate corals showing patchy bleaching $(6 \mathrm{~m}$ at Site SW2); (e) Heliofungia actiniformis (Quoy \& Gaimard), 3 unaffected corals showing fleshy polyps (12 $\mathrm{m}$ at Site E)

varuation was also apparent for the different categories of bleaching, especially with regard to paled corals and those that were completely affected. In size class 10.5 to $15.0 \mathrm{~cm}$, it was most clearly shown that paled corals were significantly more abundant than whitened ones, and entirely affected individuals more than partially bleached ones (Table 6). In $F$. (F.) fungites, the smallest individuals $\left(\varnothing_{\max } \leq 5 \mathrm{~cm}\right)$ were the least affected, whereas the largest ones $\left(\varnothing_{\max }>20 \mathrm{~cm}\right)$ showed the highest degree of bleaching. The other species also displayed a relatively low proportion of affected small corals but in contrast to $F$. ( $F$.) fungites, they showed a small percentage of affected large corals as well (Table 6)

Since the low bleaching in large corals on the outer reef might have been depth-dependent, and partial bleaching in particular (Table 4), 1-way ANOVAs and regression analyses were performed for the largest outer reef populations (Fig. 5) to analyse whether the coral length varied and even corresponded with depth. In most populations the mean coral length varied significantly (Table 7 ). Exceptions are populations of Fungia (F.) fungites at Sites W, E and SE, and of $F(P$.) paumotensis at Site SW1. 
Table 4. Percentages of mushroom corals affected by different categories of bleaching (paled or whitened, partial or entire) and their totals at various depths (measured in $2 \times 10 \mathrm{~m}^{2}$ quadrats) at 7 sites around Pari Island. Statistics $\left(\chi^{2}\right)$ are given on differences between bleaching categories per depth and on variations in the degrees of bleaching among outer reef depths $\mathrm{n}=$ number of corals per depth

\begin{tabular}{|c|c|c|c|c|c|c|c|c|c|c|}
\hline \multirow[t]{2}{*}{ Degree } & \multirow{2}{*}{$\begin{array}{c}\text { Inner } \\
\text { reef } \\
\text { flat }\end{array}$} & \multicolumn{7}{|c|}{ Depth at outer reef (m) } & \multirow{2}{*}{$\begin{array}{c}\text { Total } \\
\text { outer } \\
\text { reef }\end{array}$} & \multirow{2}{*}{$\begin{array}{c}\chi^{2} \\
\text { outer } \\
\text { reef }\end{array}$} \\
\hline & & 1 & 2 & 3 & 6 & 9 & 15 & 21 & & \\
\hline Pale & 10 & 25 & 27 & 36 & 34 & 20 & 0 & 2.5 & 27 & $51.07^{*} \cdots$ \\
\hline White & 4 & 13 & 31 & 25 & 26 & 18 & 3 & 2.5 & 21 & $29.13^{\cdots} \cdot$ \\
\hline$\chi^{2}$ pale-white & 3.21 & 0.31 & 0.23 & 3.48 & 1.75 & 0.58 & 0.67 & 0.00 & 6.57 & \\
\hline Significance & ns & ns & $\mathrm{ns}$ & $\mathrm{ns}$ & ns & ns & ns & $\mathrm{ns}$ & $\cdot$ & \\
\hline Part & 5 & 10 & 15 & 19 & 30 & 25 & 1.5 & 5 & 21 & $36.72 \cdots$ \\
\hline Whole & 9 & 28 & 43 & 42 & 30 & 13 & 1.5 & 0 & 27 & $60.08 \cdots$ \\
\hline$\chi^{2}$ part-whole & 1.12 & 0.88 & 12.95 & 19.24 & 0.00 & 8.62 & 0.00 & 0.00 & 5.62 & \\
\hline Significance & ns & ns & $\cdots$ & $\cdots$ & ns & $\because$ & ns & ns & $\cdot$ & \\
\hline Total & 14 & 38 & 58 & 61 & 60 & 38 & 3 & 5 & 48 & $80.54 \cdots$ \\
\hline $\mathrm{n}$ & 267 & 42 & 198 & 470 & 429 & 504 & 115 & 39 & 1797 & \\
\hline
\end{tabular}

Table 5. Mushroom coral populations ( $\mathrm{n}_{\mathrm{tor}}>5$ individuals) and their assemblage on the outer reef of Pari Island. Percentages of individuals affected by different categories of bleaching (paled or whitened, partial or entire) and their totals are presented Statistics $\left(x^{2}\right)$ are given on differences between bleaching categories per species, and on variations in the degree of bleaching among the species

\begin{tabular}{|c|c|c|c|c|c|c|c|c|}
\hline Species & Pale & White & $x^{2}$ & Part & Whole & $x^{2}$ & Total & $\mathrm{n}_{\text {tor }}$ \\
\hline Fungia (V.) concinna & 28 & 18 & $3.66 \mathrm{~ns}$ & 25 & 21 & $0.60 \mathrm{~ns}$ & 46 & 408 \\
\hline Fungia (V.) repanda & 50 & 25 & $8.20^{\cdots}$ & 32 & 43 & $1.63 \mathrm{~ns}$ & 75 & 224 \\
\hline Fungia (D.) horrida & 31 & 17 & $0.81 \mathrm{~ns}$ & 31 & 17 & $0.81 \mathrm{~ns}$ & 48 & 67 \\
\hline Fungia (D.) scruposa & 10 & 41 & $3.28 \mathrm{~ns}$ & 30 & 21 & $0.08 \mathrm{~ns}$ & 51 & 47 \\
\hline Fungia (F.) fungites & 29 & 25 & $0.51 \mathrm{~ns}$ & 17 & 37 & $15.27 \cdots$ & 54 & 458 \\
\hline Fungia (P.) paumotensis & 26 & 26 & $0.00 \mathrm{~ns}$ & 22 & 30 & $1.96 \mathrm{~ns}$ & 52 & 328 \\
\hline Heliofungia actiniformis & 1 & 0 & $0.67 \mathrm{~ns}$ & 0 & 1 & $0.67 \mathrm{~ns}$ & 1 & 121 \\
\hline Ctenactis echinata & 2 & 19 & $3.80 \mathrm{~ns}$ & 10 & 11 & $0.04 \mathrm{~ns}$ & 21 & 61 \\
\hline Herpolitha limax & 9 & 0 & $3.63 \mathrm{~ns}$ & 9 & 0 & $3.63 \mathrm{~ns}$ & 9 & 11 \\
\hline Sandalolitha robusta & 23 & 23 & $0.00 \mathrm{~ns}$ & 30 & 16 & $0.15 \mathrm{~ns}$ & 46 & 30 \\
\hline Podabacia crustacea & 0 & 24 & $1.20 \mathrm{~ns}$ & 14 & 10 & $0.75 \mathrm{~ns}$ & 24 & 21 \\
\hline All fungiids & 27 & 21 & $6.57^{\circ}$ & 21 & 27 & $5.62^{\circ}$ & 48 & 1797 \\
\hline$x^{2}$ & 68.41 & 35.31 & & 39.49 & 56.70 & & 76.77 & \\
\hline Significance level & $\cdots$ & $\cdots$ & & $\cdots$ & $\cdots$ & & $\cdots$ & \\
\hline
\end{tabular}

Furthermore, in most of the populations, coral length appeared to have a significant positive correlation with depth, especially in those that were most abundantly represented at the greatest depths (Fig. 5). This was usually not so for $F$. (F.) fungites with only a total of 3 (unaffected) specimens at $15 \mathrm{~m}$, at Sites SE and SW1 (Fig. 5i, 1).

\section{DISCUSSION}

During the 1983 coral bleaching around Pari Island, many coral species, such as those belonging to the branching genera Acropora, Pocillopora and Monti- pora, suffered from high mortality rates (Brown \& Suharsono 1990). For most Fungiidae, however, it was little more than a sublethal incident. Mushroom corals may be relatively heat-tolerant as evidenced by experiments (Edmondson 1928, Coles et al. 1976, Jokiel \& Coles 1977, Yang et al. 1980).

Without the occurrence of the unaffected Heliofungia actiniformis, the investigated sites around Pari Island would not have shown a significant variation in the degree of bleaching. The high coral density of this species at Site E may be related to its migratory capability (Abe 1939) and to its high number of recruits (Fig. 5h: $\varnothing_{\max } \leq 5 \mathrm{~cm}$ ), which could have been asexu- 


\section{$\begin{array}{lllllllll}\text { I.r.f. } & 1 \mathrm{~m} & 2 \mathrm{~m} & 3 \mathrm{~m} & 6 \mathrm{~m} & 9 \mathrm{~m} & 15 \mathrm{~m} & 21 \mathrm{~m}\end{array}$}

W
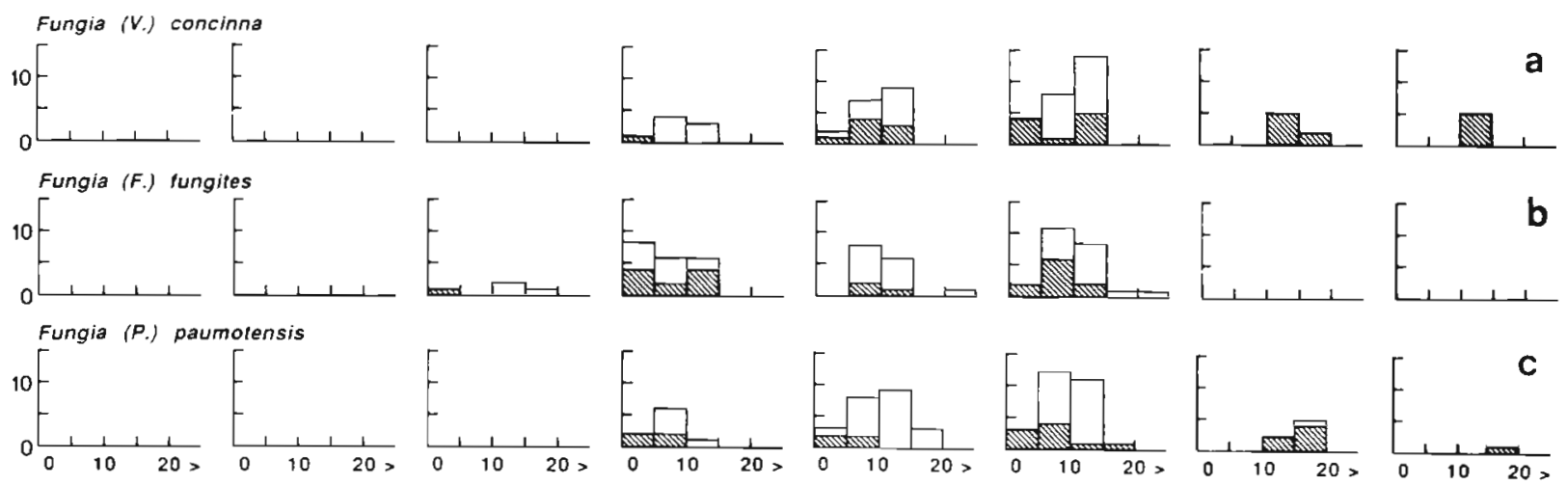

NW
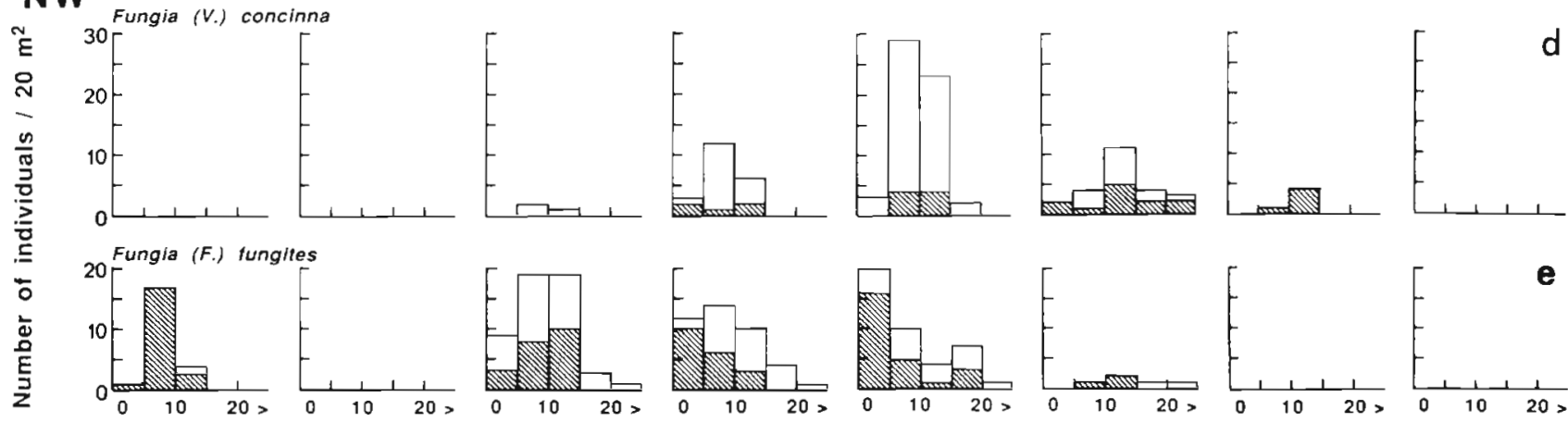

N
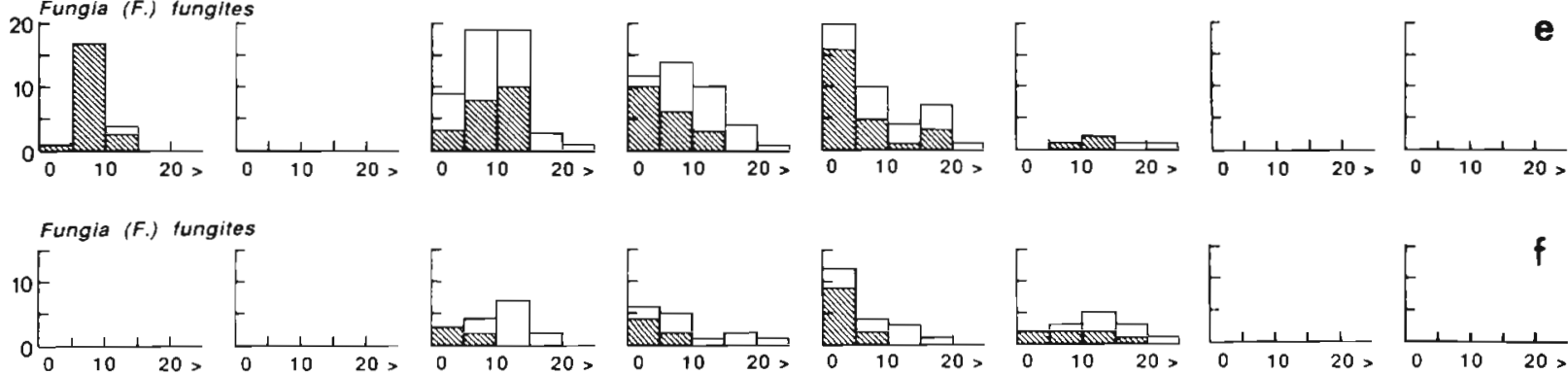

E
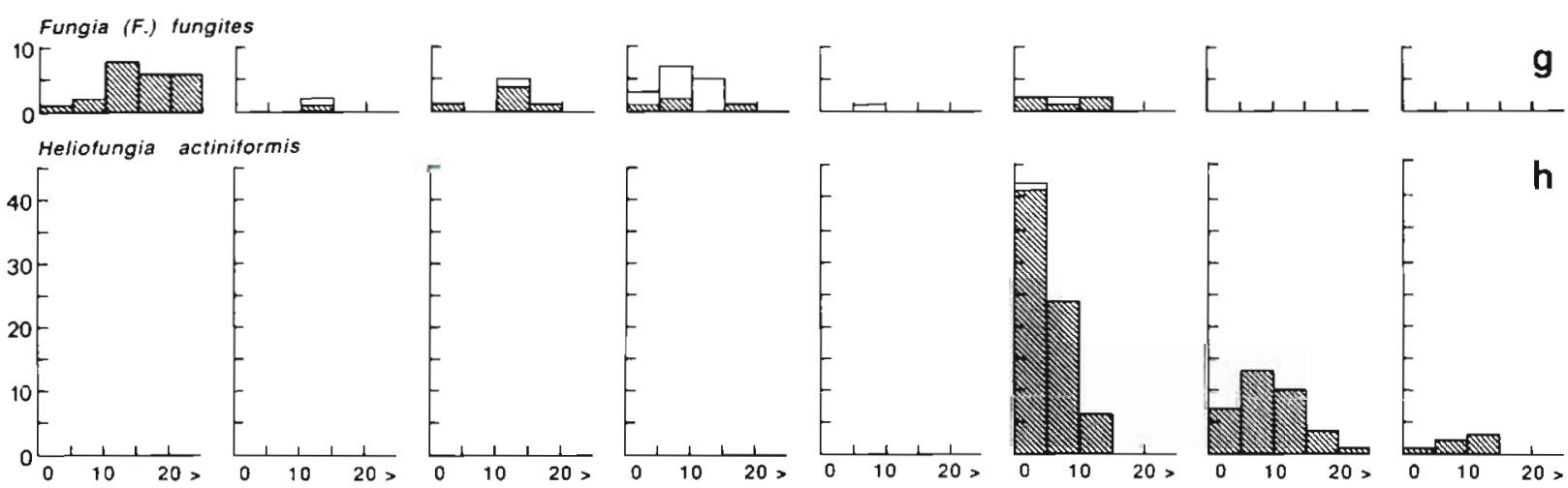

Coral length $(\mathrm{cm})$

Fig. 5. Transects with mushroom coral populations $(n>50$ ) divided into size classes and the numbers of bleached (open bars) and unaffected corals (hatched) in the investigated $2 \times 10 \mathrm{~m}^{2}$ quadrats (depths indicated above)

ally derived by regeneration from previously empty stalks (Hoeksema 1989, 1990). That corals of this species remained unaffected (Fig. 4e) may be due to the thick layer of gastrodermis in which their zooxanthellae are embedded, or its green fluorescent pigment in the epidermis (Kawaguti 1944); both may provide protection against intense sunlight

The bleaching event at Pari Island was preceded by an unusually protracted cloud-free period (Brown \& Suharsono 1990). Since coral species are not equally 


\section{$\begin{array}{lllllllll}\text { I.r.f. } & 1 \mathrm{~m} & 2 \mathrm{~m} & 3 \mathrm{~m} & 6 \mathrm{~m} & 9 \mathrm{~m} & 15 \mathrm{~m} & 21 \mathrm{~m}\end{array}$}

SE
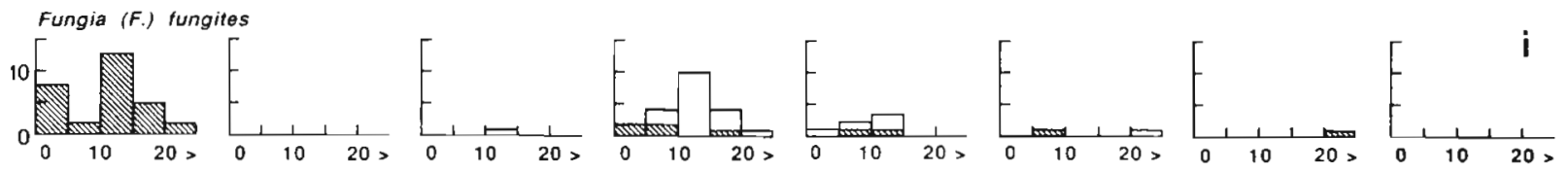

\section{SW1}
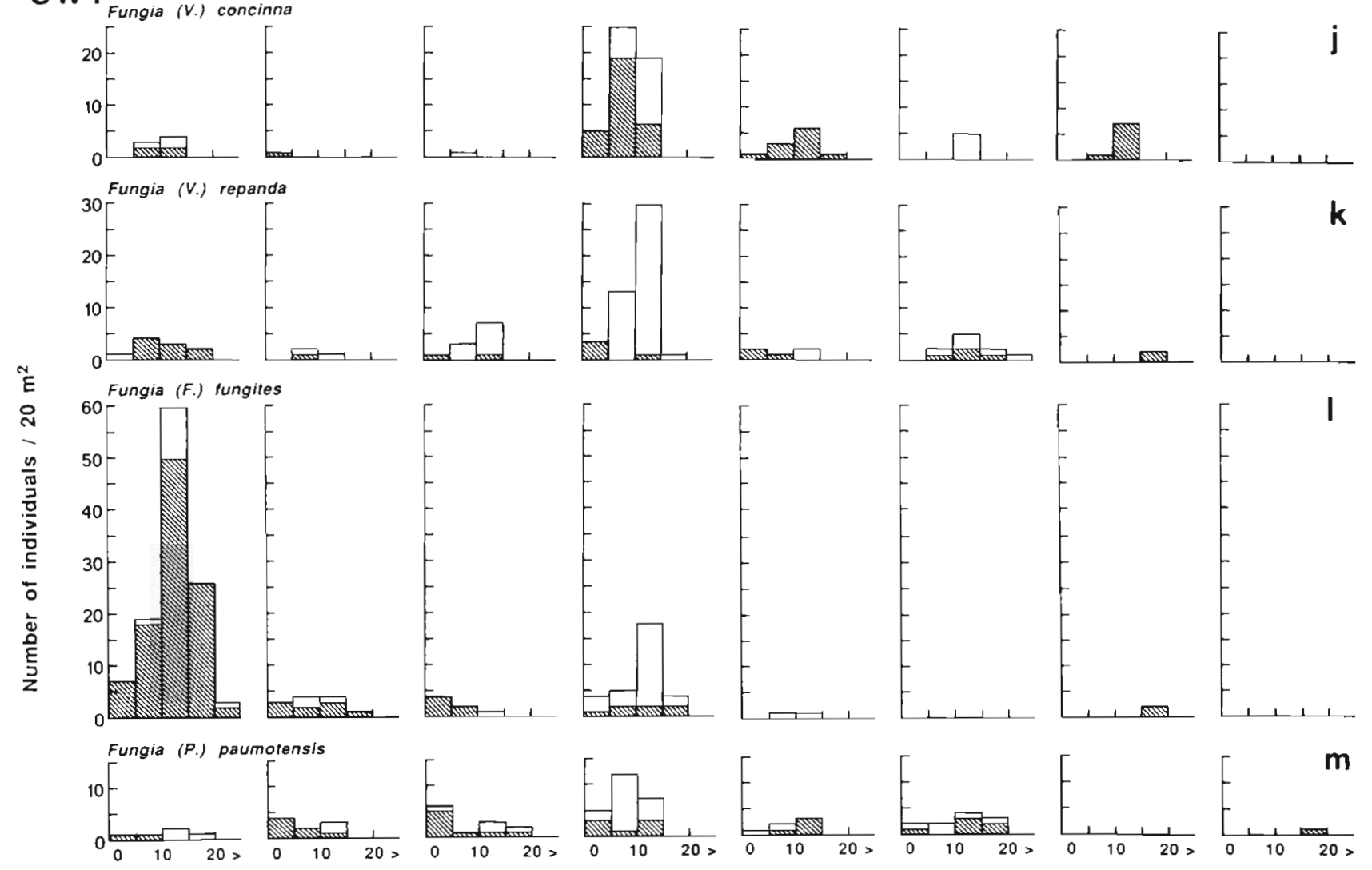

SW 2
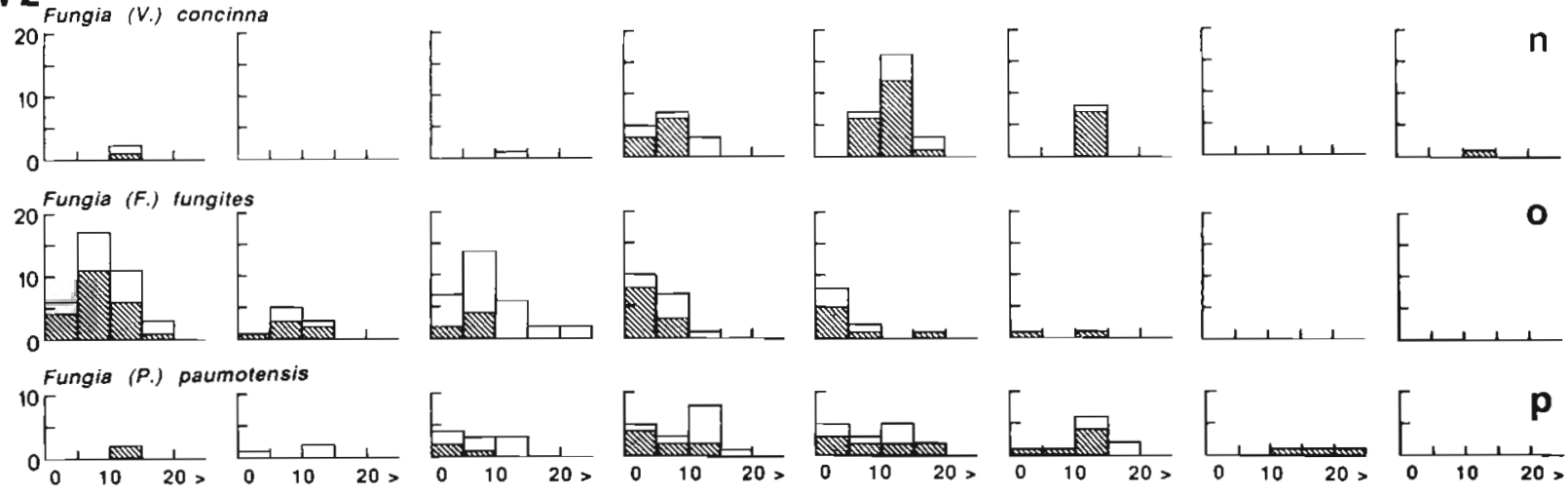

Coral length $(\mathrm{cm})$

protected by UV-absorbing compounds (Siebeck 1988), a synergistic effect of high seawater temperature and ultraviolet radiation (Harriot 1985) may also lead to different bleaching rates. Furthermore, closely related coral species can contain dissimilar strains or species of zooxanthellae (Trench \& Blank 1987, Rowan \& Powers 1991a, bj, which may show different physiological tolerances. For example, Fungia (V.) repanda corals showed a predominantly shallow distribution (Fig. 3), which does not account exclusively for the high bleach- 
Table 6. Size classes of Fungia (F.) fungites and all other mushroom coral species together on outer reef quadrats around Pari Island. Percentages of individuals affected by various categories of bleaching (paled or whitened, partial or entire, and their totals). Statistics $\left(x^{2}\right)$ on differences between categories of bleaching are given per size class. Per category, a statistic on variation among size classes is indicated; $n=$ number of corals per size class

\begin{tabular}{|c|c|c|c|c|c|}
\hline \multirow{2}{*}{$\begin{array}{l}\text { Species } \\
\text { Bleaching category }\end{array}$} & \multicolumn{5}{|c|}{ Size class $(\mathrm{cm})$} \\
\hline & $0.5-5.0$ & $5.5-10.0$ & $10.5-15.0$ & $15.5-20.0$ & $>20.0$ \\
\hline \multicolumn{6}{|l|}{ Fungia (F.) fungites: } \\
\hline Pale: $\quad 29 \% ; x^{2}=21.58 \cdots$ & 9 & 27 & 52 & 36 & 31 \\
\hline White: $25 \% ; \hat{\chi}^{2}=4.61 \mathrm{~ns}$ & 17 & 27 & 21 & 32 & 61 \\
\hline$x^{2}$ pale-white & $1.26 \mathrm{~ns}$ & $0.00 \mathrm{~ns}$ & $4.35^{\circ}$ & $0.00 \mathrm{~ns}$ & $0.17 \mathrm{~ns}$ \\
\hline Part: $\quad 17 \% ; \chi^{2}=7.70 \mathrm{~ns}$ & 7 & 23 & 24 & 18 & 23 \\
\hline Whole: $37 \% ; \chi^{2}=14.60^{\circ}$ & 19 & 31 & 49 & 50 & 69 \\
\hline$x^{2}$ part-whole & $2.70 \mathrm{~ns}$ & $0.66 \mathrm{~ns}$ & $8.03^{\cdots}$ & $2.54 \mathrm{~ns}$ & $0.71 \mathrm{~ns}$ \\
\hline Total: $\quad 54 \% ; \chi^{2}=14.60^{*}$ & 26 & 54 & 73 & 68 & 92 \\
\hline $\mathrm{n}$ & 129 & 141 & 131 & 44 & 13 \\
\hline \multicolumn{6}{|l|}{ Other Fungiidae: } \\
\hline Pale: $\quad 26 \%: \chi^{2}=28.70 \cdots$ & 11 & 25 & 37 & 26 & 12 \\
\hline White: $20 \% ; \hat{\chi}^{2}=12.07^{\circ}$ & 8 & 23 & 22 & 20 & 21 \\
\hline$x^{2}$ pale-white & $0.11 \mathrm{~ns}$ & $0.13 \mathrm{~ns}$ & $8.30^{\cdots}$ & $0.46 \mathrm{~ns}$ & $0.66 \mathrm{~ns}$ \\
\hline Part: $\quad 22 \%: \chi^{2}=11.99^{\circ}$ & 10 & 24 & 24 & 26 & 21 \\
\hline Whole: $24 \%: \chi^{2}=29.45 \cdots$ & 9 & 24 & 35 & 20 & 12 \\
\hline$x^{2}$ part-whole & $0.01 \mathrm{~ns}$ & $0.00 \mathrm{~ns}$ & $4.87^{\circ}$ & $0.46 \mathrm{~ns}$ & $0.66 \mathrm{~ns}$ \\
\hline Total: $\quad 46 \% ; \chi^{2}=35.29 \cdots$ & 19 & 48 & 59 & 46 & 33 \\
\hline n & 225 & 388 & 490 & 151 & 85 \\
\hline
\end{tabular}

Table 7 Summary results of 1-way ANOVA and least squares linear regression analyses with regard to length and depth of mushroom corals of the outer reef populations indicated in Fig. 5. ANOVAs show variation in mean coral length among investigated depths. Slope $(S)$ indicates how much coral growth in a population (length, $\mathrm{cm}$ ) corresponds with an increase in depth $(\mathrm{cm}) ; \mathrm{n}=$ number of outer reef individuals per site

\begin{tabular}{|c|c|c|c|c|c|}
\hline \multirow[t]{2}{*}{ Site } & \multirow[t]{2}{*}{ Species } & \multirow{2}{*}{$\begin{array}{c}\text { ANOVA } \\
F\end{array}$} & \multicolumn{2}{|c|}{ Linear regression } & \multirow[t]{2}{*}{$\mathrm{n}$} \\
\hline & & & r & S & \\
\hline \multirow[t]{3}{*}{ W } & Fungia (V.) concinna & $6.81 \cdots$ & $0.477^{\cdots}$ & 0.033 & 74 \\
\hline & Fungia ( $F$.) fungites & 2.34 ns & $0.219 \mathrm{~ns}$ & 0.037 & 63 \\
\hline & Fungia (P.) paunotensis & $7.33 \cdots$ & $0.463^{\cdots} \cdot$ & 0.052 & 67 \\
\hline \multirow[t]{2}{*}{ NW } & Fungia (V.) concinna & $5.80^{\cdots} \cdot$ & $0.336 \cdots$ & 0.043 & 111 \\
\hline & Fungia $(F$.) fungites & $3.00^{\circ}$ & $0.024 \mathrm{~ns}$ & 0.006 & 137 \\
\hline $\mathrm{N}$ & Fungia (F.) fungites & $3.20^{\circ}$ & $0.039 \mathrm{~ns}$ & 0.008 & 65 \\
\hline \multirow[t]{2}{*}{$E$} & Fungia ( $F$.) fungites & $2.60 \mathrm{~ns}$ & $-0.375^{\circ}$ & -0.059 & 32 \\
\hline & Heliofungia actiniformis & $7.36^{\cdots} \cdot$ & $0.332 \cdots$ & 0.044 & 110 \\
\hline SE & Fungia (F.) fungites & $1.47 \mathrm{~ns}$ & $0.271 \mathrm{~ns}$ & 0.053 & 31 \\
\hline \multirow[t]{4}{*}{ SW1 } & Fungia (V.) concinna & $4.83^{\cdots}$ & $0.459^{\cdots} \cdots$ & 0.043 & 65 \\
\hline & Fungia (V.) repanda & $3.70^{\cdots}$ & $0.413 \cdots$ & 0.049 & 78 \\
\hline & Fungia (F.) fungites & $4.78^{\cdots}$ & $0.420^{\prime} \cdot$ & 0.073 & 54 \\
\hline & Fungia (P.) paumotensis & $1.03 \mathrm{ris}$ & $0.311^{\circ}$ & 0.038 & 64 \\
\hline \multirow[t]{3}{*}{ SW2 } & Fungia (V.) concinna & $14.65^{\cdots} \cdot$ & $0.529^{\cdots} \cdot$ & 0.088 & 50 \\
\hline & Fungia (F.) fungites & $2.52^{\circ}$ & $-0.116 \mathrm{~ns}$ & -0.028 & 71 \\
\hline & Fungia (P.) paumotensis & $3.72^{\cdots}$ & $0.457 \cdots$ & 0.064 & 56 \\
\hline
\end{tabular}

ing rate of this species. Two times as many of its individuals were paled instead of whitened (Table 5); this is not clearly related to depth (Table 4). Other species, some with nearly similar bathymetric distributions, were significantly less affected. Were pigmentation decrease in zooxanthellae primarily caused by bright light, but zooxanthellae expulsion mainly induced by high temperature (Hoegh-Guldberg \& Smith 1989), it would be likely that paling in an assemblage of mushroom corals primarily depended on how much the algae in separate species were photoadapted (or protected by their host) and whitening 
would be mainly related to the bathymetric range of the warmed surface layer. This would explain why interspecific variation in paling is much higher than in whitening (Table 5).

Adjacent individuals of the same species may vary from unaffected to entirely whitened, which may be attributed to differences in their genotypes (Jokiel \& Coles 1990). Nevertheless, partial and entire bleaching in mushroom corals could clearly be distinguished as depth-related (Table 4). In the shallow part of the outer reef, most clearly at 2 and $3 \mathrm{~m}$ depth, the majority of affected fungiids was completely bleached, whereas downward, especially at $9 \mathrm{~m}$, partial discoloration was more common (Fig. 4d). A similar change in discoloration pattern was also noticed by Jaap (1985), who assumed that entire bleaching in corals occurred mainly in shallow, uniformly hyperthermic water, whereas partial bleaching could have been caused by sunken pockets of hot hypersaline water that penetrated layers of cooler subsurface water. However, Hayes \& Bush (1990) believed that homogeneous extrinsic conditions around corals may also cause variable mosaic patterns of bleaching, namely by inducing different responses to stress within the individuals concerned. Partial bleaching may also be due to differences in light exposure, which results in relatively shaded parts being the least affected (Goenaga et al. 1989, Goreau \& Macfarlane 1990). However, in mobile mushroom corals it is not necessarily clear which part of the surface was most exposed (Hoeksema 1988); their usually light-colored underside suggests that prolonged darkness may also cause low zooxanthella concentrations (cf. Yonge \& Nicholls 1931a, b).

Although a bathymetric relation with regard to coral bleaching has been observed at other localities (Faure et al. 1984, Fisk \& Done 1985, Jaap 1985, Oliver 1985. Lang et al. 1988), it was hitherto only little known that individuals living on the shallow inner reef and in lagoons could be less affected than conspecifics on the outer reef, at similar and greater depths (Goreau \& Macfarlane 1990). Only inner-reef-flat fungiids at Sites SW1 and SW2, near a tidal channel in which strong currents prevail (Fig. 1), showed noticeable bleaching. Water exchange and consequent temperature fluctuations could have been higher at these sites than at the rest of the inner reef flat and therefore might have prevented a high thermal resistance in the mushroom corals here. Coles \& Jokiel (1978) found that pre-exposure of corals to temperatures in the upper sublethal range could increase their tolerance to heat. The present results also agree with observations by Cook et al. (1990), who found more extensive coral bleaching on offshore reefs than in lagoons and on inshore reefs with presumed higher temperatures. Furthermore, Glynn \& $D^{\prime}$ Croz (1990) found that corals from an area with low- temperature upwelling were more sensitive to experimental high temperatures than those from a neighboring area without upwelling.

The size-dependent bleaching of mushroom corals is probably largely connected to their life histories (Hoeksema 1989: Fig. 42). In juvenile stage, corals of most species live attached and usually well hidden on shaded limestone substrata (Dinesen 1983), whereas later on they become free-living and able to disperse over the reef substratum (Hoeksema 1988). The freeliving corals on the reef slope are likely to migrate downward with increasing age and size (Hoeksema 1988); this explains why positive correlations can be found between size and depth of the corals. Accordingly, corals living below the bleaching zone $(\geq 15 \mathrm{~m}$ depth) have the greatest $\varnothing_{\max }$, which explains at least partly why the largest fungiids $\left(\varnothing_{\max }>20 \mathrm{~cm}\right)$ on the slope are less affected than smaller ones. Fungia ( $F$.) fungites is an exception, since it rarely showed any correlation between size and depth (Table 7). This species is known to display a predominantly shallow recruitment and little downward migration (Hoeksema 1988, 1990); therefore it was rarely found below $15 \mathrm{~m}$ (Figs. 3 \& 5). Consequently, it showed a disproportionally high number of large affected individuals (Table 7); this was most clearly demonstrated at Sites W, NW, N. SE, and SW2 (Fig. 5b, e, f, i, o).

Acknowledgements. Dr Maya R. R. B. Best encouraged me to study mushroom corals at Pulau Pari. I thank Dr Aprilani Soegiarto, Deputy Chairman for Natural Sciences of the Indonesian Institute of Sciences (LIPI), for supporting the research, and Director and staff of the Center for Oceanological Research and Development (PPPO) for hospitality and assistance. I am much indebted to family E. Martono, especially Mr. C. Martono, for logistic support in Jakarta. I am grateful to Drs R. P. M. Bak, B. E. Brown, S. D. Cairns, E. Gittenberger, E. C. Peters, and 2 anonymous reviewers for valuable comments on the manuscript. Financial support was provided by the Melchior Treub Foundation.

\section{LITERATURE CITED}

Abe, N. (1939). Migration and righting reaction of the coral, Fungia actiniformis var. palawensis Döderlein. Palao trop. biol. Stn Stud. 4: 671-694

Acevedo, R., Goenaga, C. (1986). Note on coral bleaching after a chronic flooding in southwestern Puerto Rico Caribb. J. Sci. 22: 225

Bak, R. P. M. (1978). Lethal and sublethal effects of dredging on reef corals. Mar. Pollut. Bull. 9: 14-16

Brown, B. E. (1987). Worldwide death of corals - natural cyclical events or man-made pollution? Mar. Pollut. Bull. 18: $9-13$

Brown, B. E., Holley, M. C., Sya'rani, L., Le Tissier, M. (1983) Coral assemblages of reef flats around Pulau Pari, Thousand Islands, Indonesia. Atoll Res. Bull. 281. 1- 17

Brown, B. E., Howard, L. S. (1985). Assessing the effects of 'stress' on reef corals. Adv. mar. Biol. 22: 1-63 
Brown, B. E., Suharsono (1990). Damage and recovery of coral reefs affected by El Niño related seawater warming in the Thousand Islands, Indonesia. Coral Reefs 8: 163-170

Coles, S. L., Jokiel, P. L. (1978). Synergistic effects of temperature, salinity and light on the hermatypic coral Montipora verrucosa. Mār. Biol. 49: 187-195

Coles, S. L., Jokiel, P. L., Lewis, C. R. (1976). Thermal tolerance in tropical versus subtropical Pacific reef corals. Pacif. Sci. 30: 159-166

Cook, C. B., Logan, A., Ward, J., Luckhurst, B., Berg Jr, C. J. (1990). Elevated temperatures and bleaching on a high latitude coral reef: the 1988 Bermuda event. Coral Reefs 9 : $45-49$

Dinesen, Z. D. (1983). Shade-dwelling corals of the Great Barrier Reef. Mar Ecol. Prog. Ser. 10: 173-185

Dustan, P. (1982). Depth-dependent photoadaptation by zoo xanthellae of the reef coral Montastrea annularis. Mar Biol. 68: 253-264

Edmondson, C. H. (1928). The ecology of an Hawaiian coral reef. Bull Bernice P. Bishop Mus. 45: 1-64

Faure, G., Guillaume, M., Payri, C., Thomassin, B. A., Van Preat, M., Vasseur, P. (1984). Sur un phénomène remarquable de blanchiment et de mortalité massive des madréporaires dans le complexe récifal de l'île Mayotte (SW Océan Indien). C. r. hebd. Séanc. Acad. Sci., Paris (Sér. III) 299: $637-642$

Fisk, D. A., Done, T J. (1985). Taxonomic and bathymetric patterns of bleaching in corals, Myrmidon Reef (Queensland). Proc. 5th Int. Coral Reef Congr., Tahiti 6: 149-154

Ghiold, J., Smith, S. H. (1990). Bleaching and recovery of deep-water, reef-dwelling invertebrates in the Cayman Islands, B. W. I. Caribb. J. Sci. 26: 52-61

Gladfelter, E. H. (1988). The physiological basis of coral bleaching. NOAA Nat. Undersea Res. Prog. Res. Rep. 82: $15-18$

Glantz, S. Z. (1988). Primer of biostatistics: the program McGraw-Hill, New York

Glynn, P. W. (ed.) (1990). Global ecological consequences of the 1982-83 El Niño-Southern Oscillation. Elsevier Oceanogr. Ser 52, Amsterdam

Glynn, P. W., D'Croz, L. (1990). Experimental evidence for high temperature stress as the cause of El Niño-comcident coral mortality. Coral Reefs 8: 181-191

Goenaga, C., Vicente, V P., Armstrong, R. A. (1989). Bleaching induced mortalities in reef corals from La Parguera Puerto Rico: a precursor of change in the community structure of coral reefs? Caribb. J. Scl. 25: 59-65

Goreau, T J., Macfarlane. A. H. (1990). Reduced growth rate of Montastrea annularis following the 1987-1988 coralbleaching event. Coral Reefs 8: 211-215

Harger, J. R. E. (1986). Responses of coral reef communities to environmental variables in the Kepulauan senbu. UNESCO Rep. mar. Sci. 46: 164-173

Harriott, V. J. (1985). Mortality rates of scleractinian corals before and during a mass bleaching event, Mar. Ecol. Prog. Ser. 21: 81-88

Hayes, R. L., Bush., P. G. (1990). Microscopic observations of recovery in the reef-building scleractinian coral, Montastrea annularis, after bleaching on a Cayman reef. Coral Reefs 8: 203-209

Hoegh-Guldberg, O., Smith, G. J. (1.989). The effect of sudden changes in temperature, light and salinity on the population density and export of zooxanthellae from the reef corals Stylophora pistillata Esper and Seriatopora hystrix Dana. J. exp. mar Biol. Ecol. 129: 279-303

Hoeksema, B. W. (1988). Mobility of free-living funguid corals (Scleractinia), a. dispersion mechanism and survival strategy in dynamic reef habitats. Proc. 6th Int. Coral Reef Symp., Australia 2: 715-720

Hoeksema, B. W (1989). Taxonomy, phylogeny and brogeography of mushroom corals (Scleractinia: Fungiidae). Zool Verh., Leiden 254: 1-295

Hoeksema, B. W. (1990). Systematics and ecology of mushroom corals (Scleractinia: Fungiidae). Ph. D. thesis, Leiden University. Leiden

Jaap. W C. (1985). An epidemic zooxanthellae expulsion during 1983 in the lower Florida Keys coral reefs: hyperthermic etiology. Proc. 5th Int. Coral Reef Congr., Tahiti 6 : $143-148$

Jokiel, P. L. (1988). Is photoadaptation a critical process in the development, function and maintenance of reef communities? Proc. 6th Int. Coral Reef Symp., Australia 1: $187-192$

Jokiel, P. L., Coles, S. L. (1977). Effects of temperature on the mortality and growth of Hawaiian reef corals. Mar. Biol. 43: 201-208

Jokiel, P. L., Coles, S. L. (1990). Response of Hawaiian and other Indo-Pacific reef corals to elevated temperature. Coral Reefs 8: 155-162

Kawaguti، S. (1944). On the physiology of reef corals. VI. Study on the pigments. Palao trop. biol. Stn Stud. 2 $617-673$

Kleppel, G. S., Dodge, R. E., Reese, C. J. (1989). Changes in pigmentation associated with the bleaching of stony corals. Limnol. Oceanogr 34: 1331-1335

Lang, J. C., Wicklund, R. I., Dill, R. F. (1988). Depth- and habitat-related bleaching of zooxanthellate reef organisms near Lee Stocking Island, Exuma Cays, Bahamas. Proc. 6th Int. Coral Reef Symp., Australia 3: 269-274

Moll, H., Suharsono (1986). Distribution and abundance of reef corals in Jakarta Bay and Kepulauan Seribu. UNESCO Rep. mar Sci. 46: 112-125

Oliver, J. (1985). Recurrent seasonal bleaching and mortality of corals on the Great Barrier Reef. Froc. 5th Int. Coral Reef Congr., Tahiti 4: 201-206

Ongkosongo, O. S. R., Sukarno (1986). Background to the study sites in the Bay of Jakarta and Kepulauan Seribu. UNESCO Rep. mar. Sci. 46: 56-79

Peters, E. J., Pilson, M. E. Q. (1985). A comparative study of the effects of sedimentation on symbiotic and asymbiotic colonies of the coral Astrangia danae Milne Edwards and Haime 1849. J. exp. mar. Biol. Ecol. 92: 215-230

Purwanto, J. (1987). The stress effect on coral reef ecosystem of Pari Island, Indonesia. Biotrop spec. Publ., Bogor 29. 93-109

Robinson, A., Polunin, N., Kvalvagnaes, K., Halim, M. (1981). Progress in creating a marine reserve system in Indonesia. Buil. mar. Sci. 31. 774-785

Rogers, C. S. (1983). Sublethal and lethal effects of sedments applied to common Caribbean reef corals in the field. Mar. Pollut. Bull. 14: 378-382

Rowan, R., Powers, D. A. (1991a). A molecular genetic classification of zooxanthellae and the evolution of animal-algal symbioses. Science 251: 1348-1351

Rowan, R, Powers, D A. (1991b). Molecular genetic identufication of symbrotic dinoflagellates (zooxanthellae). Mar. Ecol. Prog. Ser 71: 65-73

Siebeck, O. (1988). Experimental investigation of UV tolerance in hermatypic corals (Scleractinia). Mar. Ecol. Prog. Ser 43: 95-103

Soemodihardjo, S. (ed.) (1986). Proceedings of MAB-COMAR regional workshop on coral reef ecosystems: their management practices and research/training needs, Bogor UNESCO: MAB-COMAR \& LIPI. Jakarta 
Steen, R. G., Muscatine, L. (1987). Low temperature evokes rapid exocytosis of symbiotic algae by a sea anemone. Biol. Bull. mar biol. Lab, Woods Hole 172: 246-263

Suharsono, Kiswara, W. (1984). Natural death of corals in the Java Sea. Oseana 9: 31-40. (Indonesian)

Sukarno, (1987). The effect of environmental trends and associated human damage on coral reefs in the Seribu Islands, Jakarta. Biotrop spec. Publ., Bogor 29: 111-121

Szmant, A. M., Gassman, N. J. (1990). The effects of prolonged 'bleaching' on the tissue biomass and reproduction of the reef coral Montastrea annularis. Coral Reefs 8: 217-224

Trench, R. K., Blank, R. J. (1987). Symbiodinium microadriaticum Freudenthal, S. goreauii sp. nov., S. kawagutii., S. pilosum sp. nov.; gymnodinoid dinoflagellates symbionts of marine invertebrates. J. Phycol. 23: 469-481

Umbgrove, J. H. F. (1929). The coral reefs of the Thousand

This article was submitted to the editor
Islands (Java Sea). Wetensch. Meded. Dienst Mijnb. Nederl. Indië 12: 1-47 (in Dutch)

Williams, E. H., Bunkley-Williams, L. (1990). The world-wide coral reef bleaching cycle and related sources of coral mortality. Atoll Res. Bull. 335: 1-71

Yang, R. T., Yeh, S. Z., Sun, C. L. (1980). Effects of temperature on reef corals in the Nan-Wan Bay, Taiwan. Spec Publ. Inst. Oceanogr., College Sci., National Taiwan Univ. 23: 1-27

Yonge, C. M., Nicholls, A. G. (1931a). Studies on the physiology of corals. IV The structure, distribution and physiology of the zooxanthellae. Scient. Rep. Gt Barrier Reef Exped. 1928-29 1: 135-176

Yonge, C. M., Nicholls, A. G. (1931b). Studies on the physiology of corals. $V$ The effect of starvation in light and in darkness on the relationship between corals and zooxanthellae. Scient. Rep. Gt Barrier Reef Exped. 1928-29 1 177-211

Manuscript first received: December 20, 1990

Revised version accepted: June 4, 1991 